\title{
GŁOS W DYSKUSJI 0 TEKŚCIE STAROPOLSKIM. ZNAD KANONÓW MSZY ŚW.
}

Słowa klucze: tekst staropolski, glosa, tłumaczenie w średniowieczu, kanon mszy św., funkcja tekstu, intencja pisarza

Keywords: Old Polish text, gloss, translation in the Middle Ages, Canon of the Mass, function of the text, intention of the scribe

Niniejsze rozważania są inspirowane artykułem Tomasza Miki Tekst staropolski jako odmienny obiekt badań? W poszukiwaniu narzędzi opisu, w którym zaproponował on nowe spojrzenie na teksty dawne:

Uważam, że tekst staropolski, w szczególności średniowieczny tekst rękopiśmienny, jest innym obiektem badawczym niż późniejsze teksty. Ujawniają to zarówno ostatnio prowadzone badania, jak również próba odniesienia zdobyczy współczesnej tekstologii do tekstu średniowiecznego (Mika 2015: 235),

przyczyn ich odmienności upatrując przede wszystkim „w samych tekstach (postać tekstu) i w sytuacji ich powstawania i funkcjonowania" (ibid.: 236).

T. Mika wskazuje kilka typów zabytków, wobec których nowa perspektywa myślenia o tekście staropolskim jest szczególnie interesująca. Należą do nich zabytki glosowane:

Podobnie atrakcyjne wydaje się odniesienie pytań tekstologicznych do tekstów glosowanych, zarówno jedno-, jak i dwujęzycznych. Czy glosy są częścią tekstu? A jeśli tak, to czyjego (problem ,jedności nadawcy")? Glosy bywały przecież wpisywane przez kolejne ręce, często po długim czasie od zapisania tekstu głównego. Jeśli uznać je za część tekstu, to jak opisać nadawcę takiego tekstu? Czy i jak glosowanie zmieniało 
funkcję i przeznaczenie tekstu (powszechnie uważa się na przykład polskie glosy w kazaniach łacińskich za dowód przygotowania do ich głośnej realizacji w języku wernakularnym)? Pytania można by mnożyć. Być może wskazywany tu kierunek pozwoli na usprawnienie narzędzi opisu w sytuacjach najtrudniejszych, kiedy glos jest tak dużo i tak są związane już nie tylko z tekstem głównym, ale i pomiędzy sobą, że zaczynają tworzyć odrębny tekst. [...] Czy układające się w pełne tłumaczenie glosy wpisane inną ręką to inny tekst (co za tym idzie - inny język, inny odbiorca, nowy układ intencji i funkcji)? Czy glosatorów traktować li tylko jako użytkowników rękopisu, czy też jako nadawców wtórnych? (ibid.: 241-242, 246-247).

Badacz formułuje problemy na dość wysokim poziomie ogólności. Rzecz wymaga dokładnego rozważenia $\mathrm{w}$ odniesieniu do poszczególnych średniowiecznych tekstów, a szczególnie interesująca wydaje się w przypadku jednej, dotąd niemal nieopisanej grupy zabytków glosowanych ${ }^{1}$, odnośnie do których badacze używają sformułowań „bardzo liczne glosy”, „glosy układające się w tekst” etc. W zachowanych polskich (polsko-łacińskich) średniowiecznych zabytkach znajduje się kilka rękopisów, które opisywane są w taki właśnie sposób²:

1. Tzw. Kazania augustiańskie (rkps Biblioteki Jagiellońskiej, sygn. Akc 110/56). Są to 24 karty pochodzące $\mathrm{z}$ większego zbioru łacińskich kazań; pierwsze trzy zawierają bardzo liczne polsko-łacińskie (z przewagą polskich) dopiski marginalne i interlinearne, które, jak piszą Wiesław Wydra i Wojciech Rzepka, „tworzą prawie kompletny przekład tekstu łacińskiego" (2004: 108).

2. Rękopis Biblioteki Narodowej, sygn. 3019 III. Zawiera on kazania, zbiory egzemplów oraz lekcje ewangeliczne. Nad jedną z nich „nadpisane zostały obfite glosy polskie, które tworzą prawie kompletny przekład wersetów 1-9 XXI rozdziału Ewangelii wg św. Mateusza" (ibid.: 84).

3. Tzw. Ewangeliarz kanoników regularnych w Krakowie (rkps Biblioteki kanoników regularnych w Krakowie, sygn. 933). W kodeksie zapisano 107 kazań, z których osiem rozpoczyna się fragmentem ewangelii opatrzonym „obfitymi glosami polskimi, tworzącymi prawie ciągły przekład [...] perykop" (Pietkiewicz 2013: 35).

4. Kanony mszy św. Wśród zachowanych 17 średniowiecznych redakcji zawierających polskie glosy do kanonu mszy św. znajduje się siedem, o których pisze się jako o „prawie kompletnym tłumaczeniu kanonu rzymskiego” (Leńczuk 2013: 6) czy też „zapisach [...], które ze względu na ich spójność można uznać za teksty” (ibid.: 69); są to rękopisy: IV, VI, VIII, XII, XIV, XVI³. W ten sposób pisze się też o rękopisie III, jednak w tym przypadku polskie tłumaczenie nie ma formy

1 Dotychczas charakteryzowano tylko poszczególne zabytki, co więcej, niemal żaden z nich nie został poddany analizie i całościowo opisany.

2 Problem ten sygnalizowałam już na marginesie rozważań nad propozycją wydania Kazań augustiańskich, zob. Masłej (w druku).

3 Numeracja zgodnie z wydaniem Mariusza Leńczuka (2013). 
glos do tekstu łacińskiego. Mariusz Leńczuk stwierdza, że ,jest to wypadek wyjątkowy, ponieważ polski tekst istnieje w nim praktycznie bez swojej łacińskiej podstawy" (ibid.: 65).

Dodajmy, że do tego specyficznego typu zabytków należą tylko rękopisy pierwotnie wyłącznie łacińskie (także kopie tekstów łacińskich, w których już znajdują się nieliczne polskie glosy wciągnięte do tekstu głównego ${ }^{4}$ ). Taki system „rozbudowanego glosowania" jest zatem bezpośrednio związany z procesem adaptowania określonych tekstów do języka polskiego (także z przygotowaniem ich do realizacji w języku narodowym) i ściśle wiąże się z dokonującym się w średniowiecznej Polsce procesem wernakularyzacji5.

Przedstawiony powyżej sposób mówienia o tych zabytkach pozwala sądzić, że są one ze względu na kryterium formalne (miejsce wpisania na karcie) uznawane za glosy, z drugiej strony ich postać (stopień rozbudowania) każe badaczom myśleć o nich jako o tekstach. Jest to jednak myślenie wynikające wyłącznie z kształtu oraz liczby dopisków. W świetle nowych badań nad tekstem staropolskim wydaje się, że nie jest to jedyne kryterium, na którego podstawie można uznać tego typu zapisy za teksty.

Pytanie postawione przez Mikę (2015: 241): „czy i jak glosowanie zmieniało funkcję i przeznaczenie tekstu" trzeba w przypadku tego typu zabytków uzupełnić o kolejne pytania: kiedy proces glosowania prowadził do powstania kolejnego tekstu, kiedy (z dzisiejszej perspektywy) możemy mówić o odrębnym, nowym tekście? Co decyduje o jego odrębności i co powinno cechować dany zapis, aby mógł on zostać uznany za tekst? Każdy z wymienionych tu zabytków musi być traktowany osobno. Wszystkie bowiem są do siebie podobne zewnętrznie, natomiast - jak pokaże przedstawiona $\mathrm{w}$ niniejszym artykule analiza wybranych kanonów mszy św. ${ }^{6}$ - nie wystarczy patrzeć na nie przez pryzmat zagęszczenia oraz liczby glos, by udzielić odpowiedzi na sformułowane pytania.

Jak wiadomo, tylko nieliczne polskojęzyczne zabytki średniowieczne są znane z wielu redakcji (por. Wydra 1973; Leńczuk 2013; Masłej 2016). Kanon mszy św. jest jednym $\mathrm{z}$ tych tekstów, które przetrwały w wielu XV-wiecznych odpisach w wersji łacińskiej, a w $17 \mathrm{z}$ nich znajdują się mniej lub bardziej liczne polskie glosy będące tłumaczeniem odpowiednich słów lub całych fragmentów tekstu łacińskiego. $\mathrm{Na}$ każdy z tych zabytków badacze patrzą przez pryzmat całej grupy: ze względu na różną liczbę glos poszczególne warianty charakteryzuje się pod względem ilościowym, używa się w ich kontekście sformułowań opisujących je jako „pojedyncze glosy” lub nawet „prawie kompletne przekłady”. Trzeba zauważyć, że w opisie glos jako „prawie

\footnotetext{
4 Tak jest w przypadku Kazań augustiańskich.

5 Studium na temat funkcjonalności i przydatności tego terminu na gruncie polskich badań historycznojęzykowych jest w przygotowaniu.

6 Analiza pozostałych wskazanych zabytków - w przygotowaniu.
} 
kompletnego przekładu" presuponuje się tekstowość 7 i, co szczególnie ważne, intencję glosatora. O wszystkich tych zabytkach pisze się bowiem, że

tekst polski miał służyć przede wszystkim duchowieństwu parafialnemu, co w sposób bezpośredni wiąże się z ustawami synodalnymi nakazującymi archidiakonom w czasie wizytacji egzaminowanie księży z rozumienia modlitw kanonu (Leńczuk 2013: 58, wyróżnienie - D.M.).

Umieszczenie wszystkich zabytków z tej grupy na jednej linii: pojedyncze glosy kompletne tłumaczenie jest zbyt daleko idącym uogólnieniem, zacierającym specyfikę poszczególnych zabytków, co pokażę na wybranych (właśnie według kryterium ilościowego) czterech rękopisach z tej grupy: Mszy III, Mszy IV, Mszy XII i Mszy XVI. Dlatego też analiza tych zabytków obejmie, oprócz kompletności tłumaczenia, także inne elementy: postać graficzną, składnię, podstawę tłumaczenia.

\section{Postać graficzna}

Jak wspomniałam, wyjątkowy we wskazanej grupie jest rękopis Mszy III. Tylko tutaj tłumaczenie kanonu mszy św. zostało zapisane nie (jak w pozostałych przypadkach) między liniami, nad odpowiednimi fragmentami łacińskiego tekstu, ale osobno poszczególne fragmenty znajdują się przeważnie na górnym lub dolnym marginesie kart: 2r, 4r, 5v, 6r, 8ra, 8rb, 11vb, 13vb, 15vb, 16ra, 25vb, 30vb, 32rb, 33va, 33vb, 35rb, $37 \mathrm{ra}, 37 \mathrm{rb}, 39 \mathrm{rb}, 42 \mathrm{ra}, 44 \mathrm{rb}, 44 \mathrm{va}, 44 \mathrm{vb}, 45 \mathrm{ra}, 45 \mathrm{rb}$.

Zestawienie kart, na których znajdują się polskie ustępy, uwidacznia brak linearności całego tłumaczenia. Jest ono rozpisane na 19 kart (znajdujących się wśród pierwszych 45 kart zabytku), w skrajnym przypadku dwa polskie fragmenty - ściśle związane ze sobą pod względem tematycznym, mowa bowiem o konsekracji chleba i konsekracji wina - dzieli 9 kart tekstu łacińskiego ${ }^{8}$. Dopiero ułożenie kolejnych polskich części w jedną całość w edycji (zob. ibid.: 180-199) pozwala stwierdzić, że tworzą one kompletne tłumaczenie łacińskiego tekstu kanonu.

7 M. Leńczuk zauważa: „Używane w literaturze przedmiotu sformułowania: »tłumaczenie kanonu«, "przekład kanonu« oraz »staropolski kanon« sugerują, że polski tekst kanonu jest kompletny, logiczny, spójny gramatycznie i składniowo oraz że funkcjonował autonomicznie, czyli istniał samodzielnie, bez swojej łacińskiej podstawy. Tak jednak nie było" (Leńczuk 2013: 55) - niestety myśli tej autor nie rozwija.

8 Zapiska na k. 16r kończy się słowami: Tocz yest prawe czyalo moye, kolejny fragment, który zaczyna się słowami: Takesz gdysz weczrzaal · yest wsząw yten preswyatli kelych wszwąte ytesz welebne rancze swoye, znajduje się na k. 25 r (zob. Leńczuk 2013: 183). 


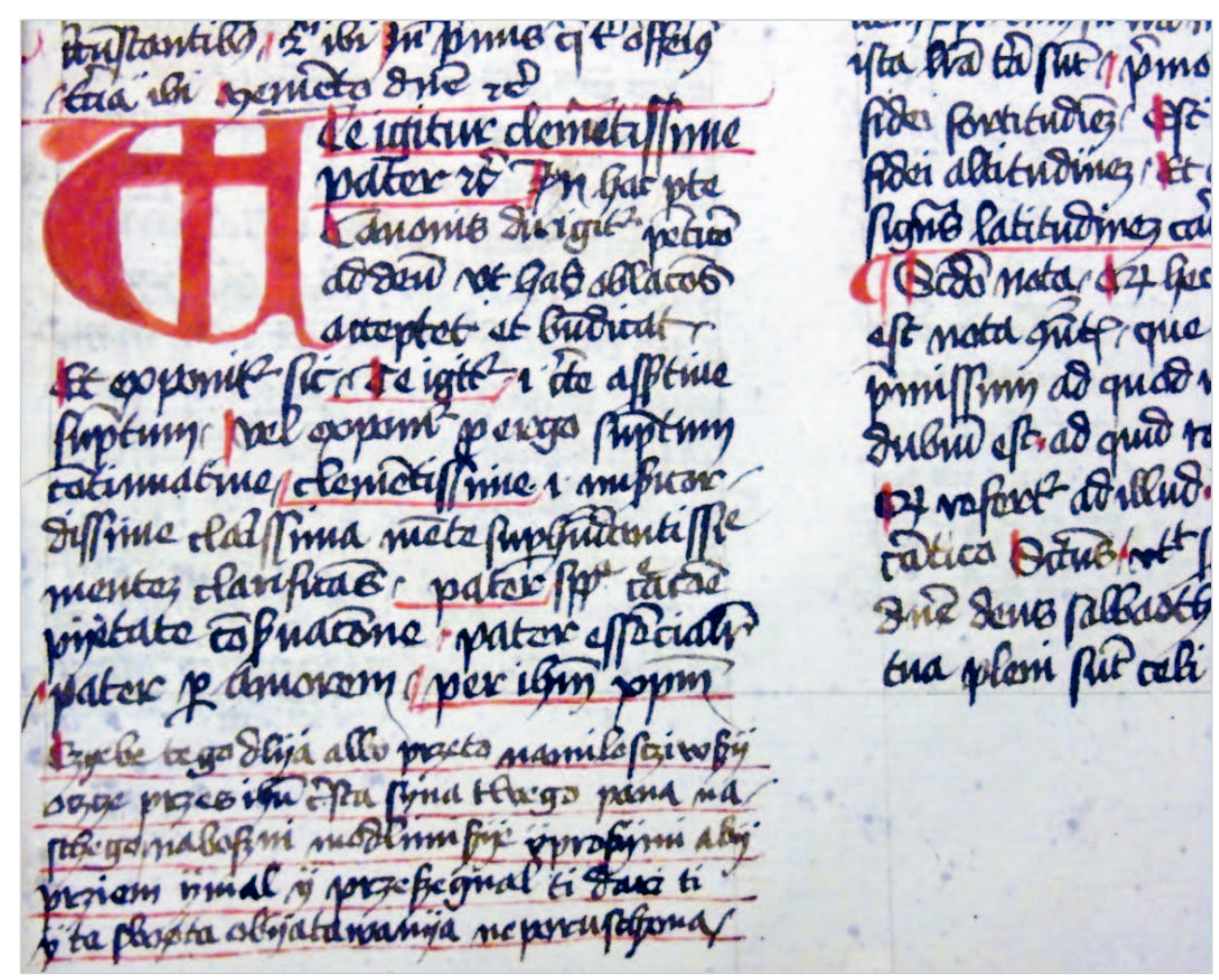

Fot. 1. Rękopis Zakładu Narodowego im. Ossolińskich we Wrocławiu, sygn. 208o/II, fragment k. $2 r^{9}$

Pozostałe analizowane kanony zawierają polskie słowa zapisane $\mathrm{w}$ formie glos interlinearnych. Rękopis Mszy IV najpewniej od początku przygotowany był do dalszej pracy, sam główny tekst zapisany został bowiem z podwójną interlinią (od początku pozostawiono $\mathrm{w}$ nim miejsce na dopiski), a glosy już od pierwszej linii rękopisu wpisywane były w interliniach wysoko, w taki sposób, aby można było wprowadzić kolejne dopiski:

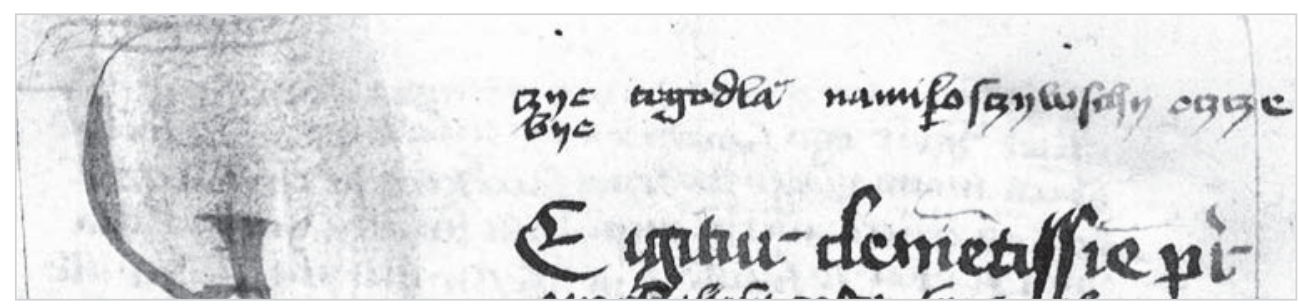

Fot. 2. Rękopis Biblioteki Jagiellońskiej, sygn. Akc. 150/54, fragment k. 244V

9 Wszystkie fotografie pochodzą z edycji M. Leńczuka (2013). Autor zgodził się na ich reprodukcję $\mathrm{w}$ artykule. 
Bardzo istotny jest sposób zapisu polskich tłumaczeń nad poszczególnymi łacińskimi słowami. Wielokrotnie wyraz jest dzielony i przenoszony do linii niżej po to, by kolejne dopisane słowo znajdowało się dokładnie nad swoim łacińskim odpowiednikiem. Widać to na fot. 2: pierwszy wyraz, łaciński zaimek te, ma w zapisie wielkie $T$, które nie było glosowane. Nad drugą literą, wielkim $E$, pomieszczono zatem całe tłumaczenie wyrazu, dzieląc je na dwie linie czye | bye, dzięki czemu dokładnie nad kolejnym łacińskim wyrazem igitur skryba mógł zapisać kolejny polski odpowiednik (tegodla). Jest to szczególnie znaczące w takich fragmentach, jak przedstawiony na fot. 3 :

\section{Thosige Oawan $=1$ Sonvay of?

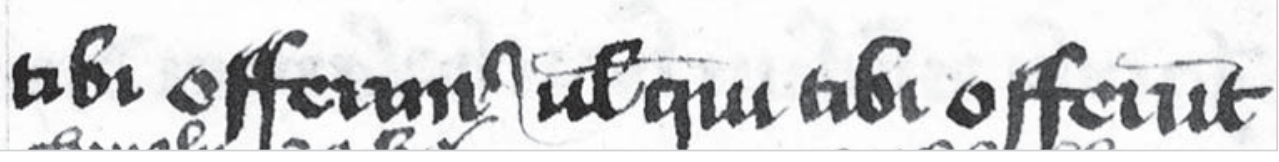

Fot. 3. Rękopis Biblioteki Jagiellońskiej, sygn. Akc. 150/54, fragment k. 245r

Nad zapisanym $\mathrm{z}$ abrewiacją czasownikiem offerun $n^{\text {tur }}$ dopisano $\mathrm{w}$ dwóch liniach uzgodnione gramatycznie polskie tłumaczenie, stosując znak podziału: dawa $=\mid m y$. Trzeba zwrócić uwagę na to, że kolejne trzy łacińskie słowa: ut qui tibi nie są glosowane, nie zostały przetłumaczone, a mimo to skryba wprowadził wspomniane dzielenie wyrazu. Wyraźnie widać, że taki zapis nie wynikał z prostego myślenia o ilości miejsca (o konieczności zmieszczenia odpowiedniej partii polskich dopisków w linii), ale był sposobem umieszczania tłumaczenia wyrazów w tym konkretnym typie zabytków. Dowodzi to, że sam glosator nie myślał o zapisywaniu tekstu, lecz precyzyjnie planował zapis tłumaczenia poszczególnych słów.

Istotne jest tu przeznaczenie tych dopisków. W literaturze przedmiotu podkreślano, że glosy polskie do kanonu mszy św. mogły być zapisywane przez studentów (tak twierdzili Aleksander Brückner, Bogdan Bolz i Wanda Żurowska-Górecka, Paweł Sczaniecki, zob. Leńczuk 2013: 57-58), bardzo często wypływały też z niewykształcenia kleru oraz konieczności elementarnego zrozumienia sprawowanej liturgii, np. w kontekście przygotowania do egzaminu (ibid.: 58-59), co wyjaśnia tak dokładny sposób zapisywania tłumaczeń.

W tej perspektywie bardzo ciekawe wydaje się tłumaczenie wyrażenia pro ecclesia sancta | catholica w Mszy IV. Jest tu ono przetłumaczone jako zaczyrkew swantø albo zazgromadzenÿe wyernego krzesczyansthwa|krzeszczyansthwa. Powtórzenie rzeczownika krześcijaństwo wynika właśnie z dydaktycznego (szkolnego) charakteru pracy skryby oraz z jego dbałości o oddawanie poszczególnych słów. Fragment zgromadzenie wiernego krześcijaństwa znajduje się nad łacińskim ecclesia sancta za- 
pisanym w jednej linii, zaś kolejny wers tekstu zaczyna się od przymiotnika catholica przetłumaczonego raz jeszcze przez rzeczownik krześcijaństwo.

Podobny układ (sposób zapisu), choć z mniejszą dbałością, zastosowano w zapisie Mszy XVI:

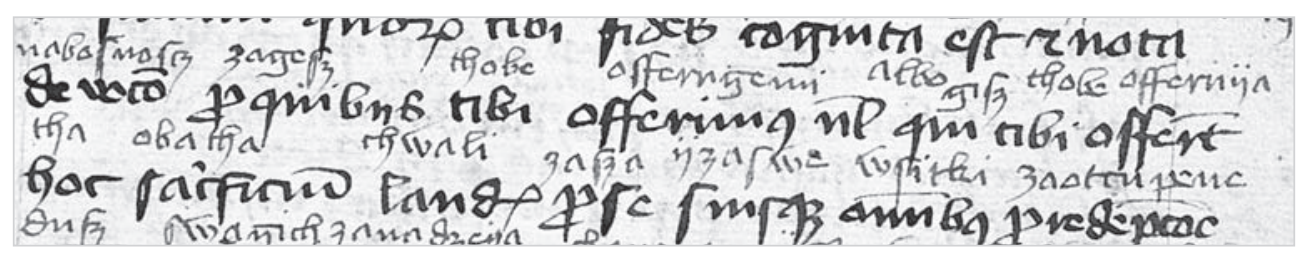

Fot. 4. Rękopis Biblioteki Narodowej w Warszawie, sygn. Akc. 9889, fragment k. 68r

W tym zabytku nie dzielono wyrazów między liniami - nie ma na to miejsca, zapewne rękopis w momencie jego tworzenia nie był przeznaczony do komentowania lub glosowania. Nie tylko nie przewidziano na dopiski miejsca w interliniach, ale także pozostawiono wąskie marginesy; ponadto tekst łaciński zapisano mniej starannie niż w analizowanym wyżej rękopisie Biblioteki Jagiellońskiej. I tutaj jednak ogląd postaci graficznej pozwala dojść do wniosku, że glosator przekładał nie tekst, ale poszczególne wyrazy, których tłumaczenie notował bezpośrednio nad łacińskimi słowami, zachowując między polskimi dopiskami takie odstępy, jakie wynikają z długości poszczególnych zapisów łacińskich ${ }^{10}$.

Rękopis Archiwum Archidiecezjalnego w Gnieźnie, czyli Msza XII, z pewnością (podobnie jak Msza IV) był od początku przeznaczony do dalszej pracy. Przy zapisie tekstu łacińskiego zachowano podwójną interlinię oraz szerokie marginesy. Glosator jednak wykorzystał je nie tylko do nadpisywania polskich odpowiedników nad poszczególnymi fragmentami łaciny, ale także do zapisywania łacińskich komentarzy do tekstu kanonu, co czyni sytuację jeszcze bardziej skomplikowaną. Przykład znajduje się na fot. 5:

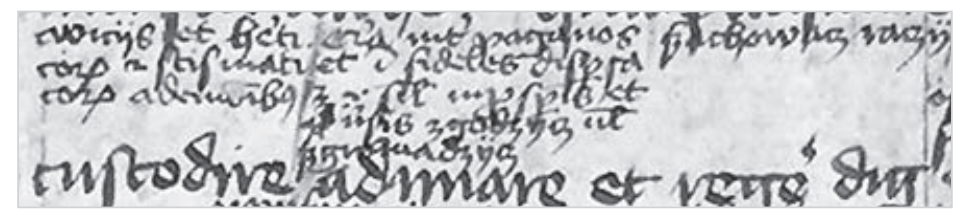

Fot. 5. Rękopis Archiwum Archidiecezjalnego w Gnieźnie, nr MS 6o, fragment k. 5rb

Nad łacińskim fragmentem custodire adunare et regere glosator zapisał łaciński komentarz, na którego końcu zamieścił dwa polskie czasowniki połączone łacińskim

$10 \mathrm{Na}$ „szkolność” zapisu wskazuje też fakt, że w tym rękopisie niektóre wyrazy polskie naśladują grafię łacińską, np. offerugemi (zob. fot. 4). Za tę uwagę bardzo dziękuję prof. Tomaszowi Mice. 
spójnikiem: zgodzycz uel szgromadzycz, będące, jak się wydaje, uzgodnionym gramatycznie tłumaczeniem łacińskiego czasownika adunare 'zjednoczyć, połączyć, skupić, zebrać. Polsko-łaciński fragment nie jest, co ważne, w żaden sposób graficznie oddzielony od łacińskiego komentarza, lecz stanowi jego kontynuację. Sama postać graficzna - umieszczenie części tłumaczenia na końcu lacińskiego komentarza - nie pozwala myśleć o zapisywaniu przez glosatora polskiego tekstu kanonu. Pierwszy czasownik, custodire 'strzec, zachować, pilnować, nie został przetłumaczony w oczekiwanym przez nas miejscu (znajduje się tu tylko fragment łacińskiego komentarza). Dopiero nad czasownikiem regere pisarz umieścił polskie słowo szachowacz. Ze względu na wskazany już sposób graficznego rozmieszczenia tłumaczonych wyrazów można się spodziewać, że zachować ma w rękopisie odpowiadać łacińskiemu czasownikowi regere 'rządzić, kierować ${ }^{\prime 1}$. W tym przypadku skryba zamienił kolejnością polskie czasowniki i to ostatni z nich nie został przełożony, choć z rozmieszczenia polskich słów nad łacińskim tekstem można by wnioskować inaczej.

\section{Składnia}

Jako świadectwo tego, że zapisywane przez glosatorów tłumaczenia w ich intencji bardzo często nie miały być tekstami, można potraktować także gromadzenie odpowiedników leksykalnych w poszczególnych zabytkach. Niektóre łacińskie fragmenty kanonu są tłumaczone na kilka sposobów, także w obrębie jednego rękopisu, co zaobserwował M. Leńczuk:

Zarówno w tekście traktatu, glosach łacińskich do kanonu, jak i w glosach polskich odnajdujemy nagromadzenie wyrazów bliskoznacznych o różnym stopniu bliskoznaczności, których zadaniem było jak najwierniejsze przybliżenie sensu modlitwy (ibid.: 68).

Według niego gromadzenie słów mogło wynikać z dopracowywania i aktualizowania „polskiego tekstu kanonu” kopiowanego ze starszych odpisów i uwspółcześnianego przez kolejnych pisarzy (zob. ibid.: 69, 79). W dwóch analizowanych tu zabytkach (Msza III, Msza IV) wielokrotnie pojawia się kilka (dwa lub więcej) odpowiedników leksykalnych ${ }^{12}$.

Polskie tłumaczenie kanonu w Mszy III, zapisane linearnie na marginesach, nie ma - jak w przypadku pozostałych zabytków - formy glos znajdujących się bezpośrednio nad poszczególnymi słowami lub konstrukcjami łacińskimi. Jest tu jednak

11 W Słowniku staropolskim wyłącznie na podstawie materiału z kanonu mszy św. uznano, że jednym ze znaczeń staropolskiego czasownika zachować jest 'prowadzić, kierować, regere, dirigere'. Wydaje się, że zaproponowana w niniejszym artykule interpretacja także jest zasadna.

12 W Mszy XII tylko w jednym miejscu, nad łacińskim rzeczownikiem sacrificium na k. 7va, zapisano w ciągu dwa tłumaczenia: obyatha offyera. 
wiele takich dopisków, co do których można domniemywać, że początkowo miały formę notowanych obok siebie lub pod sobą wariantów tłumaczeniowych, które ostatni skryba połączył w jedną całość, stosując typowy w takich sytuacjach spójnik albo (por. Twardzik 1994: 161-162; Gesner 2011: 94-95), np.:

czyebe tegodlya albo przeto namiloscziwszy oczcze (k. 2r), wspamątay albo pomni pane (k. 5v), zawykupyene albo zazbawenye duszch swych (k. 6r), roszgodz albo sądzy ytesz od wecznego potampenya nas wytargacz albo wirwacz (k. 11v).

W niektórych fragmentach widać, jak wciągnięcie glosy - drugiego wariantu zaburza składnię, np. na k. 8r zapisano następujący fragment:

pamyøcz czcząc albo chwaløcz napirzwey falebney albo slawøtney pa ${ }^{\mathrm{n}}$ ni dzewicze mariey matky bezey ypana naszego ih ${ }^{\text {es }} \mathrm{u}$ crista.

Jeśli uznać, że czasownik chwaląc został zapisany jako drugi wariant tłumaczenia łacińskiego memoriam venerantes, w przedstawionym fragmencie dostrzeżemy zdanie z właściwą rekcją (czcić pamięć + Gen.): pamięć czcząc \{albo chwaląc\} napirwej falebnej albo sławetnej pani dziewice. Widać też, że glosator nadpisujący wyraz chwaląc pracował rozpoznaną już techniką „wyrazową" - nie przeszkadzał mu brak gramatycznego uzgodnienia nadpisanego imiesłowu z przyłączaną grupą imienną.

W Mszy IV odpowiedniki leksykalne zapisywane są jeden pod drugim ${ }^{13}$ lub obok siebie. Niektóre z nich są wprowadzane wyrażeniem funkcyjnym albo, jednak między częścią odpowiedników nie ma żadnego spójnika. Wówczas, odczytane jako ciągły tekst, burzą spójność i budowę składniową (trudno spodziewać się budowanych asyndetycznie szeregów składniowych).

Nie da się wskazać zależności między sposobem zapisania odpowiedników (jeden pod drugim lub obok siebie) a ich wprowadzaniem do komponowanej całości, co obrazuje fragment przedstawiony na fot. 6 . Nad dwoma następującymi po sobie czasownikami łacińskimi accipite oraz manducate zapisano po dwa odpowiedniki: weszmyczye | przymyczye oraz wzyvaycze | albo geczczye.

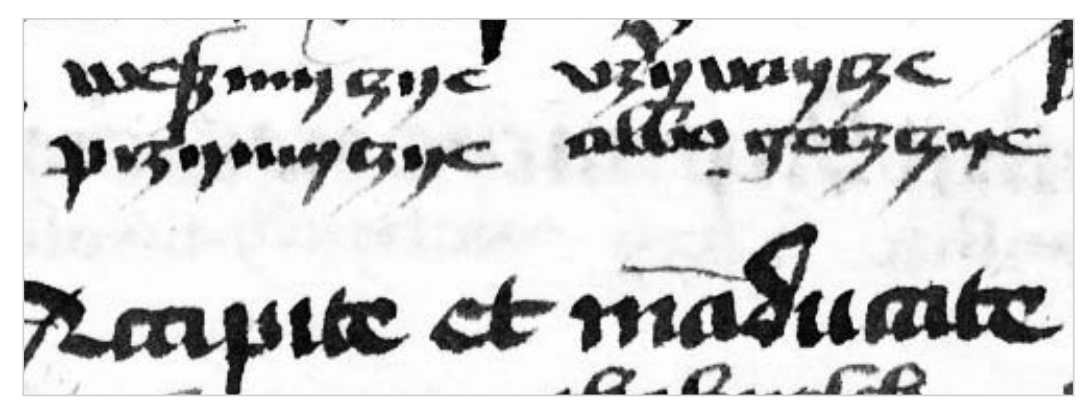

Fot. 6. Rękopis Biblioteki Jagiellońskiej, sygn. Akc. 150/54, fragment k. 246v

13 Np.: naprzo\{o\}d które dayemi obyatuyemy thobye (k. 244v), naprzothku napyrwey (k. 245r). 
Niekiedy zapisywane są obok siebie nie tylko odpowiedniki leksykalne, ale także dwie formy tego samego wyrazu, np. na k. 244v (zob. fot. 7), gdzie łacińskiej formie habeas odpowiadają dwie formy polskie: ma oraz miałby. Cała konstrukcja wygląda następująco: yako przyemnø ma myalby y przeszegnalby ty dary ${ }^{14}$. Jeśli przyjąć założenie o budowaniu przez skrybę tekstu, należałoby odczytywać ją linearnie, co w sposób oczywisty daje fragment niespójny gramatycznie i cechujący się nadmiarowością leksykalną. Skryba jednak tekstu nie budował, lecz gromadził odpowiedniki.

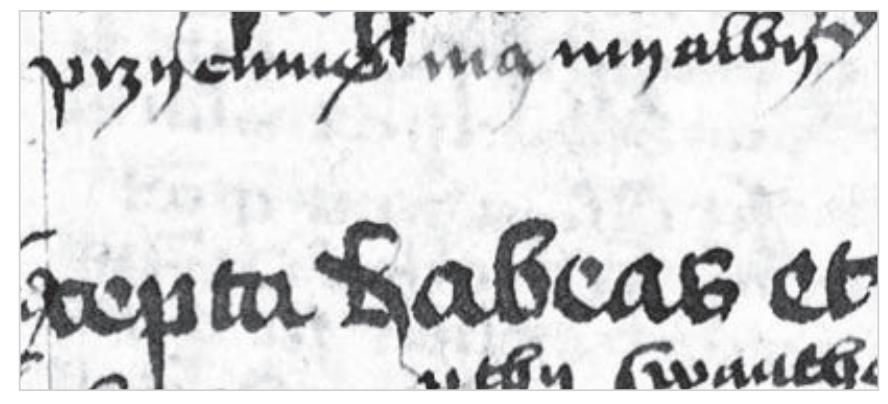

Fot. 7. Rękopis Biblioteki Jagiellońskiej, sygn. Akc. 150/54, fragment k. 244V

Podobne wnioski można wyciągnąć na podstawie analizy fragmentu tłumaczenia Mszy IV, które przedstawia fot. 8:

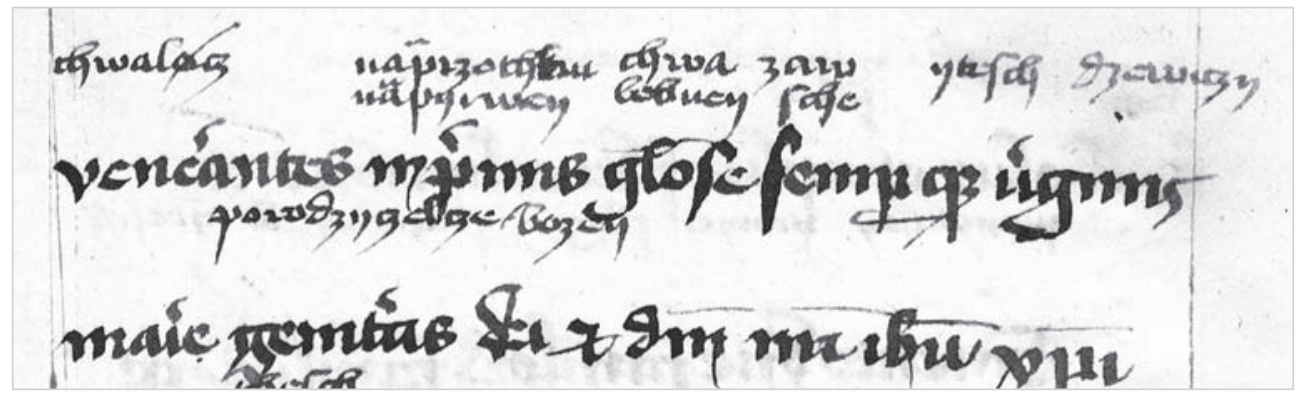

Fot. 8. Rękopis Biblioteki Jagiellońskiej, sygn. Akc. 150/54, fragment k. 245V

Łaciński fragment venerantes in primis gloriose semperque virginis marie glosator przetłumaczył jako chwaløcz na przothku napyrwey chwalebney zawsche ytesch dzewiczy, przy czym dwa tłumaczenia łacińskiego in primis znajdują się jedno pod drugim: na przothku | napyrwey. W całym rękopisie, jak już wspomniałam, glosy zapisywane były od góry, można zatem sądzić, że w pierwszej kolejności pisarz wpi-

14 W transkrypcji formę trybu oznajmującego ujęto w nawiasy kwadratowe i uznano za zbędną, zob. Leńczuk 2013: 211. 
sał tłumaczenie na przodku, w drugiej - napirwej. Być może i tu gromadził on w ten sposób różne odpowiedniki leksykalne, podobnie jak czynił to wielokrotnie, np.:

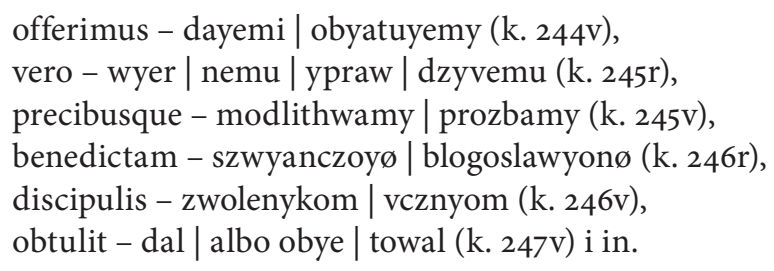

W przytoczonym wyżej fragmencie istotne jest także dosłowne tłumaczenie słów gloriose semperque virginis. W łacinie spójnik que (oznaczający między innymi 'i, oraz, także') przyłączany jest do zakończenia wyrazu, którego bezpośrednio dotyczy, w polskich konstrukcjach odpowiednik tego spójnika oczywiście poprzedza dany wyraz. Tymczasem zarówno w tym, jak i w wielu pozostałych tłumaczeniach kanonu mszy św. ${ }^{15}$ (co ważne - także w Mszy III, zapisanej osobno) oddano łacińską strukturę: chwalebnej zawsze i też dziewicy, co wprost pokazuje dbałość nie o budowanie tekstu zgodnie z polską składnią, ale właśnie o dokładne tłumaczenie wyrazów i konstrukcji łacińskich, także pod względem układu elementów językowych. W polszczyźnie nie tylko zachowywany jest łaciński szyk, ale także oddawane są dokładnie formy gramatyczne. W omówionym fragmencie venerantes in primis gloriose semperque virginis marie tłumacz zachował łacińską rekcję venerare + Dat. (venerare gloriose virginis), $\mathrm{w}$ glosie bowiem mamy chwalić + Dat. (chwalić chwalebnej dziewicy) zamiast chwalić + Acc. M. Leńczuk pisze, że w kanonach

miejsc, w których polski tekst respektuje właściwości gramatyczne tekstu łacińskiego, jest zdecydowanie więcej od tych, w których polskie glosy pod względem gramatycznym nie są ścisłym tłumaczeniem łaciny (2013: 73)

\section{Kompletność tłumaczenia}

W literaturze przedmiotu wielokrotnie podkreślano niepełność poszczególnych redakcji, pisano np. o „prawie kompletnym przekładzie”, co może świadczyć o niewyrażonym explicite założeniu badaczy, że ktoś zamierzał stworzyć kompletny

15 Np. zapis nad fragmentem Memento domine famulorum famularumque tuarum w Mszy IV (oraz podobnie w Mszy III) wygląda następująco: pamøthay panye slug sluzebnyczk ytesch twich (k. 245r).

16 Jednak M. Leńczuk przeciwstawia je nie formom właściwym polszczyźnie, ale takim, które „zachowywały jedynie wartość semantyczną tłumaczonego wyrazu [...]. W wypadku glos objaśniających, które jedynie przybliżały ogólne znaczenie łacińskiego leksemu, tłumacz nie brał pod uwagę jego cech gramatycznych" (2013: 73). 
przekład. Rozważając problem tekstu w odniesieniu do tej grupy zabytków, warto zwrócić uwagę na miejsca wymagające - z dzisiejszej perspektywy - uzupełnienia. Trzeba bowiem pamiętać, że polskie tłumaczenia z założenia nie musiały być kompletne, ponieważ nie miały one funkcjonować bez łacińskiej podstawy. Jak wiadomo, w średniowieczu przekładanie kanonu mszy św. nie wypływało z chęci sprawowania eucharystii w języku narodowym, ale przede wszystkim z potrzeb praktycznych, zwłaszcza dydaktycznych ${ }^{17}$. Wobec tego można sądzić, że tłumaczenia na język wernakularny zawsze były nierozerwalnie związane z tekstem łacińskim.

Najbardziej kompletny jest, także ze względu na postać graficzną, zapis Mszy III. Mamy tutaj do czynienia z tłumaczeniem, w którym nie oddano zaledwie kilku wyrazów z łacińskiej podstawy, co, poza nielicznymi wyjątkami, nie zaburzyło pod względem składniowym spójności polskiego tekstu.

W rękopisie Mszy IV glosator zostawiał miejsca na uzupełnienie tytułów oraz imion, zarówno tych aktualizowanych na bieżąco w ustnej realizacji łacińskiego tekstu, np. szslugø thwym <papa nostro $M>y$ thesch [...] (zob. fot. 9), jak i tych zapisanych $\mathrm{w}$ tekście głównym ${ }^{18}$ :

y tesch dzewiczy <marie> porodzyczelcze bozey <et domini nostri ihesu xpisti> Thesch <et beatorum apostolorum ac martyrum tuorum Petri et Pauli Andree Jacobi Johanis Thome Jacobi Philipi Bartholomei...> (k. 245v, zob. fot. 10).

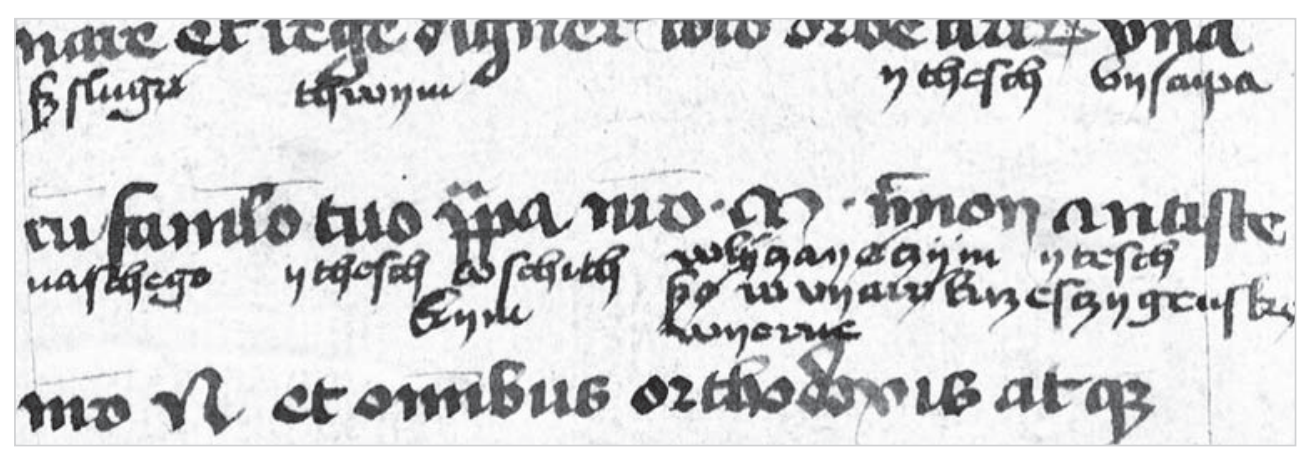

Fot. 9. Rękopis Biblioteki Jagiellońskiej, sygn. Akc. 150/54, fragment k. 244V

17 Obszernie - w oparciu o całą dostępną literaturę przedmiotu - pisze o tym M. Leńczuk, przywołując liczne źródła potwierdzające nieznajomość łaciny wśród kleru i wymogi rozumienia kanonu mszy przez księży (ibid.: 57-64).

18 Choć niekiedy zapisuje imiona Maryi i Chrystusa, por. np.: tego crista szyna thwego pana naschego blogoslawyonego (Msza IV: k. 247r). 


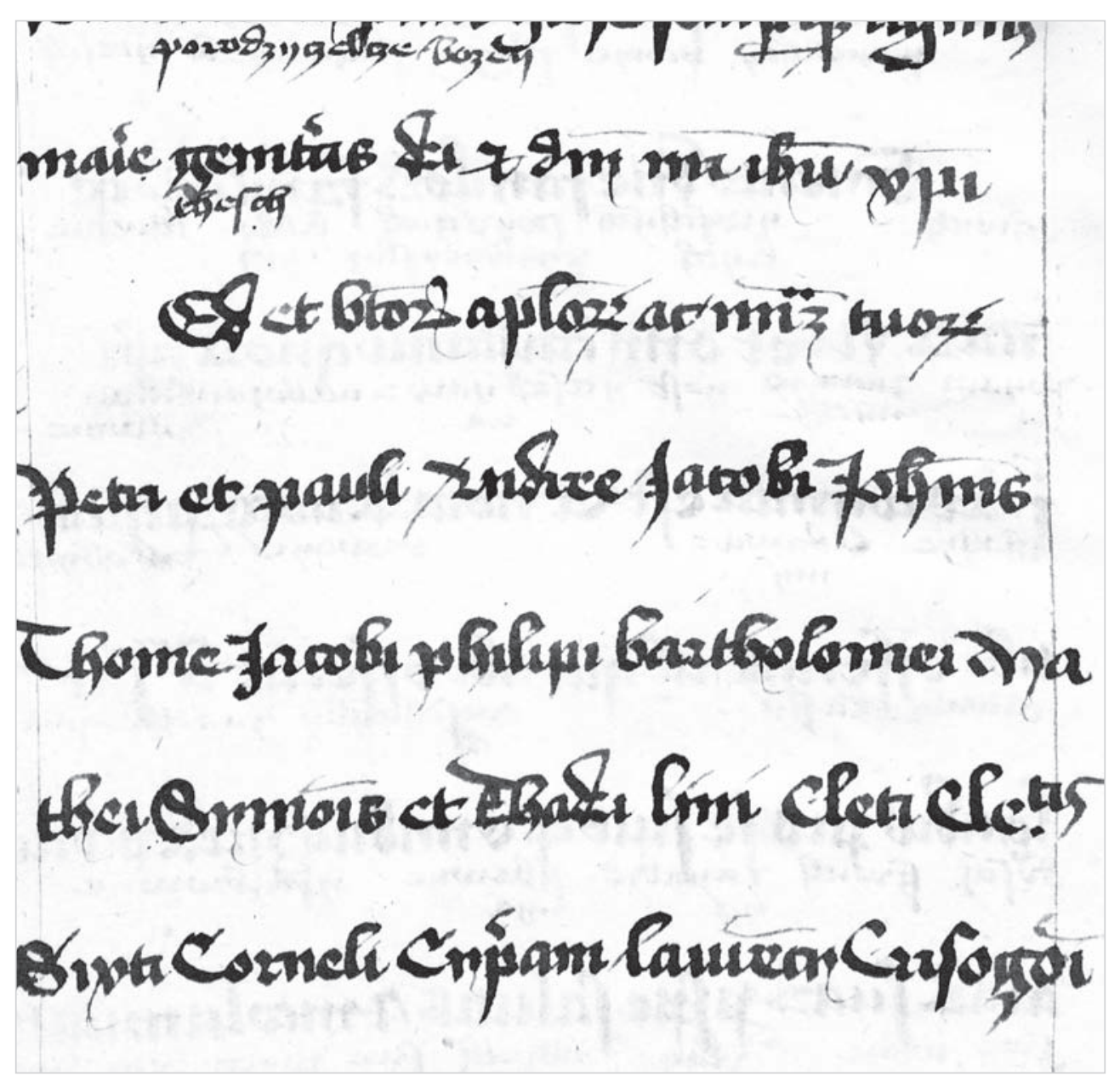

Fot. 10. Rękopis Biblioteki Jagiellońskiej, sygn. Akc. 150/54, fragment k. 245V

Podobnie rzecz ma się w obu pozostałych rękopisach, czyli w Mszy XII i Mszy $X V I$, w których pomija się tłumaczenie konwencjonalnych zwrotów, np. per ihesum cristum filium tuum dominum nostrum (Msza XII: k. 5ra), per eundem Christum dominum nostrum (Msza XVI: k. 68v), oraz imion papieża, biskupa i króla: papyezyem nyaschim <Martino $>$ ysbiskupem nyaschem <Sbigneo $>$ yskrolyem nyaschem $<$ Wladislao> (Msza XII: k. 5rb; zob. fot. 11). 


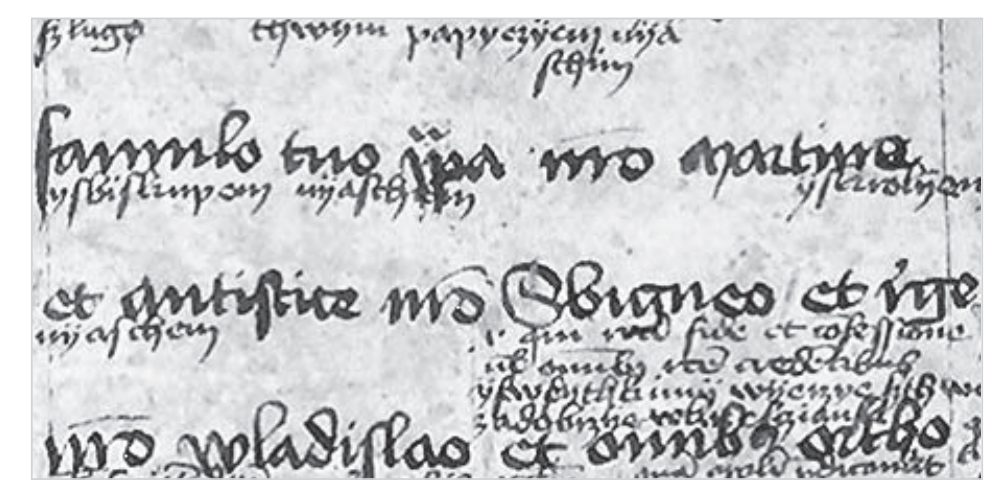

Fot. 11. Rękopis Archiwum Archidiecezjalnego w Gnieźnie, nr MS 6o, fragment k. 5rb

To, że pisarz nie tłumaczy nazw własnych związanych z konkretnym momentem dziejów (imię władcy lub papieża) bądź terytorium (imię biskupa), zdaje się dowodzić, że zwyczajowo nie przekłada się elementów oczywistych, niepotrzebnych, w tym także pewnych formuł. Można również sądzić - zwłaszcza w odniesieniu do Mszy XII, gdzie pisarz nie tłumaczy imion znajdujących się w łacińskim tekście - że celem jest przełożenie językowych składników schematu ${ }^{19}$, który będzie funkcjonalny w wielu sytuacjach, jest wystarczający do nauki, zrozumienia łacińskiego kanonu mszy św., a nie do jego realizacji w postaci tego konkretnego, zapisanego na karcie tekstu. Jest to oczywiste ze względu na przeznaczenie i wykorzystywanie tego typu rękopisów.

W tym miejscu warto zwrócić uwagę na sposób, w jaki współcześnie wydaje się staropolskie kanony mszy św. Zdradza on przekonanie wydawców, że prezentują one tekst. Dlatego zapisy niepełne, ale zawierające bardzo dużą liczbę glos (z omawianych tu rękopisów mowa przede wszystkim o Mszy XII i Mszy XVI, które wymagają najwięcej uzupełnień), są w wielu miejscach obficie uzupełniane, by z dzisiejszej perspektywy mogły zostać uznane za kompletne i spójne. W ten sposób utrwala się przekonanie o tekstowości tych zabytków.

19 Schemat rozumiem tutaj jako ukształtowany, niepodlegający zmianom (ustabilizowany) tekst, w którym występują miejsca pozostawione do obligatoryjnego wypełnienia (aktualizowania) podczas jego ustnej realizacji. W przypadku kanonu mszy św. takimi miejscami, uzupełnianymi podczas odprawiania liturgii, są imiona papieża, biskupa, zmarłych, świętego z danego dnia. W schemacie przyjmują one formę zwrotów lub fraz: „wraz ze sługą Twoim Papieżem naszym N. i Biskupem naszym N.”, „Pomnij, Panie, na sługi i służebnice Twoje N.N.”, w realizacji są uzupełniane aktualnymi danymi w zależności od czasu i miejsca sprawowania liturgii oraz intencji mszalnej. 


\section{Podstawa tłumaczenia. Świadomość tekstu}

Rozważając charakter polskich dopisków do łacińskiego kanonu mszy św., trzeba mieć na uwadze także podstawę tłumaczenia. Może nią być albo sam łaciński tekst kanonu, albo tekst wraz z łacińskimi komentarzami ${ }^{20}$. Ważne jest, że w przypadku łacińskiej podstawy mówimy o tekście kanonu mszy św., który jest tłumaczony. Efektem tłumaczenia nie jest natomiast, jak pokazały analizy, polski tekst, ale zbiór tłumaczeń poszczególnych wyrazów lub konstrukcji. Wynika to z intencji glosatora i z funkcji polskich glos do kanonu.

W poszczególnych redakcjach łacińskiej podstawy można zaobserwować nieliczne rozbieżności. Analiza M. Leńczuka wykazała, że są to przede wszystkim różnice leksykalne (zwłaszcza w obrębie wyrażeń funkcyjnych), a także uzupełnienia $\mathrm{w}$ stosunku do podstawowego tekstu. Wynikają one $\mathrm{z}$ równoległego funkcjonowania wariantów tekstu, niekiedy także ze środowiska, w którym powstał dany odpis (Leńczuk 2013: 45-52). Spostrzeżenia M. Leńczuka warto uzupełnić uwagą o charakterze genologicznym. Zapisany tekst łaciński jest najczęściej schematem wypełnianym w zależności od potrzeb w realizacji ustnej. Miejsca zmienne (np. imię papieża) są przygotowane do uzupełnienia, w tekście łacińskim czytamy np.: papa nostro $\mathrm{N}$. Niekiedy jednak (tak jest w wypadku Mszy XII) mamy do czynienia z realizacją, w której wszystkie takie miejsca są uzupełnione konkretnymi informacjami, aktualnymi w momencie tworzenia danej redakcji.

W dwóch zatem perspektywach (1. podstawą tłumaczenia jest tekst kanonu lub tekst kanonu oraz komentarze, 2. podstawą tłumaczenia jest schemat lub jego realizacja) należy rozważyć świadomość podstawy tłumaczenia u polskich glosatorów.

Kwestia różnego podejścia skrybów do tłumaczonego tekstu jest w sposób szczególny widoczna w dwóch zabytkach: Mszy XII oraz Mszy XVI. Jak już wspomniałam, glosator Mszy XII dopisywał do tekstu głównego nie tylko jego polskie tłumaczenie, ale także łacińskie komentarze. W modlitwie za Kościół (In primis) w Mszy XII czytamy: cum famulo tuo papa nostro Martino et antistite nostro Sbigneo et rege nostro Wladislao et omnibus orthodoxis \{id est qui vera fide et confesione vel omnibus vere credentibus\} atque catholice et apostolice fidei cultoribus (k. $5 \mathrm{rb}$ ). Fragment ujęty $\mathrm{w}$ nawiasy klamrowe skryba ciasno wpisał w interlinii nad zapisem et omnibus ortho (zob. fot. 12). Pod nim, w trzeciej i czwartej linijce w interlinii oraz w kolejnej linii nad drugą częścią łacińskiego słowa orthodoxis, znajduje się polskie tłumaczenie: ysewsythkimy wyerzye szthwer $\mathrm{L}_{\text {dzonimy }}$ zadobrzye $w$ krzescziansk $\mathrm{L}_{\text {skyey wyerze }}$ zywøczye (k. 5rb).

Warto ponownie zwrócić uwagę na układ graficzny tłumaczenia. Jest on świadectwem tego, że zapisywane w interliniach polskie odpowiedniki nie miały układać

20 Przy czym komentarze mogą być zapisane w interliniach, jak w wypadku Mszy XII, lub wciągnięte do tekstu głównego, jak w wypadku Mszy XVI. 
się w ciąg, ważne było natomiast ich zapisywanie w odpowiednim miejscu na karcie. Trzeba też zauważyć, że pisarz tłumaczy zarówno tekst główny, jak i fragmenty łacińskiego komentarza zapisanego między liniami (tłumaczenia łacińskich glos do kanonu mszy św. M. Leńczuk nazywa metaglosami (ibid.: 80-84)).

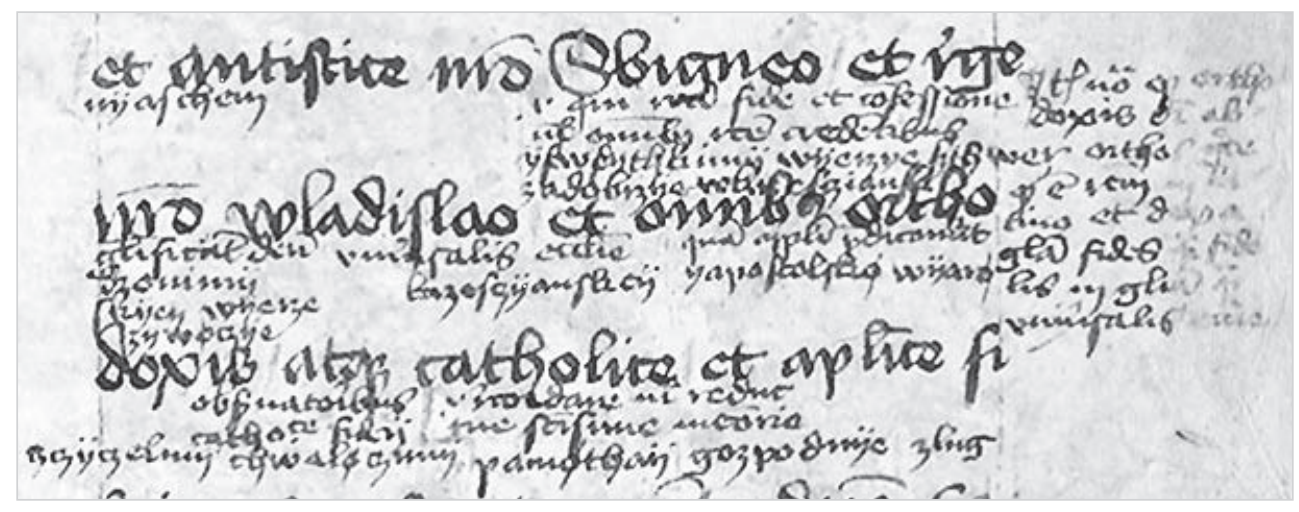

Fot. 12. Rękopis Archiwum Archidiecezjalnego w Gnieźnie, nr MS 6o, fragment k. 5rb

Zupełnie inaczej jest w rękopisie Mszy XVI. Tutaj w łaciński tekst główny zostały włączone elementy (niekiedy obszerne) genetycznie nieprzynależące do kanonu mszy św., np. na k. 68r:

Rogamus ac petimus Hic te erige Vti accepta habeas et benedicas hec do + na // Adhec dona faciat vnam crucem cum duobus digitis ita que in dextera sunt desuper et medius subtus ad hec + munera facias secundam crucem terciam ad hec san + cta sacrifcia Illibata

lub na karcie 68v:

Quam oblacionem tu deus in omnibus quesumus bene + dictam \{super totum facias vnam crucem secundam ad Adscrip + tam $\mathrm{Ra}+$ tam racionabilem acceptabilem que facere digneris vtnobis quartam hic ad cor + pus super hostiam quintam ad et sangtuis fiat dilectissimi fily tui domini nostri ihesu xpisti hic accipiat hostiam in manus et tunc dicet $[\ldots]$.

Wytłuszczone tutaj elementy nie należą do kanonicznego tekstu mszy św. i ich glosator nie przetłumaczył, skupił się na glosowaniu słów oraz konstrukcji wyłącznie z łacińskiego kanonu.

Przedstawiona analiza prowadzi do wniosku, że mimo iż w obu zabytkach znajdowały się i tekst kanonu, i komentarze (zapisane w interliniach lub wciągnięte do tekstu głównego), dla obu pisarzy co innego było podstawą tłumaczenia. Skryba Mszy XII tłumaczył zarówno tekst kanonu, jak i dopisywane do niego łacińskie glosy. Być może najważniejsze było dla niego zrozumienie jak największej liczby ele- 
mentów łacińskich zapisanych na karcie. Jeśli przyjąć tę hipotezę, można sądzić, że glosowanie służyło nauce łaciny, i uznać podejście glosatora za bardzo szkolne. Tłumaczenie słów i konstrukcji tak z kanonu, jak i z komentarzy także w tym świetle nie może być zatem uznane za budowanie tekstu. Natomiast dla glosatora Mszy XVI istotny był tylko kanoniczny tekst łaciński. Pierwszy skryba, twórca tekstu głównego, poprzez wciągnięcie do zapisywanego tekstu elementów genetycznie obcych zbudował bardziej obszerną całość (wykraczającą poza tekst kanonu), glosator zaś konsekwentnie pomijał w tłumaczeniu wszystkie te fragmenty. Choć nie stworzył polskiego tekstu (co wykazały dotychczas przedstawione analizy), to jednak miał znacznie większą świadomość podstawy tłumaczenia niż pisarz Mszy XII.

Jeśli chodzi o drugą perspektywę (schemat - jego realizacja), we wcześniejszej analizie Mszy XII starałam się dowieść, że tłumaczone były elementy składające się na schemat, a nie jego realizacja. Oczywiście nie da się stwierdzić tego z całą pewnością, trzeba bowiem brać pod uwagę wspomniany już szkolny zapis, w którym tłumaczono nie tylko tekst kanonu, ale także komentarze. Wydaje się jednak, iż nie bez znaczenia jest to, że pisarz tak uważnie oddający wszystkie łacińskie słowa szczegółowe informacje pozostawił nieprzetłumaczone ${ }^{21}$. Może to świadczyć właśnie o oczywistej potrzebie tłumaczenia elementów i struktur schematu, a nie jego konkretnej realizacji.

Przedstawione analizy pozwalają stwierdzić, że w odniesieniu do zabytków obficie glosowanych możemy mówić albo o tłumaczeniu pojedynczych słów/konstrukcji oraz o gromadzeniu odpowiedników leksykalnych, albo o próbie tworzenia przekładu tekstu. Aby uznać dany zbiór dopisków za tekst, nie wystarczy zatem odwołać się do podstawowego - i dotąd najczęściej jedynego - kryterium ilościowego (związanego z kompletnością tłumaczenia, liczbą glos). W świetle nowych badań nad tekstem staropolskim wydaje się, że trzeba je uzupełnić o kryteria wynikające $\mathrm{z}$ dwóch cech definicyjnych tekstu: funkcję tworzonej przez skrybę całości oraz intencję pisarza. Tu zaś pomocna jest wiedza historyczna oraz kulturowa dotycząca sposobów funkcjonowania zabytków danego typu oraz analiza składniowa zapisków.

Trzeba bowiem zauważyć, że przy uwzględnieniu intencji autora oraz funkcji całości spójność i kompletność nie są warunkami koniecznymi do uznania danego zabytku za tekst. W przypadku kanonów mszy św. wynika to między innymi z podstawowych cech zabytków tego typu. Jak stwierdzono wcześniej, tłumaczenia kanonu nie funkcjonowały w oderwaniu od łacińskiej podstawy. Tutaj to ona przynajmniej z perspektywy współczesnego odbiorcy (także edytora) - gwarantuje spójność tłumaczenia, pozwala dzisiejszemu wydawcy na proste uzupełnienie nieprzetłumaczonych miejsc, a tym samym (bardzo często) na budowanie lub utrwalanie przekonania o tekstowości tych zabytków. Tymczasem w wielu przypadkach

21 W pozostałych rękopisach również nie tłumaczono tych formuł, ale najczęściej pomijano je w całości. 
nawet przetłumaczenie wszystkich łacińskich słów oraz konstrukcji składniowych nie powinno decydować o tym, by polskie dopiski uznać za tekst. Wydaje się, że trzeba o nich mówić jako o kompletnym zbiorze glos. Przemawia za tym zarówno ich postać graficzna (nadpisywanie pojedynczych słów czy konstrukcji bezpośrednio nad ich łacińskimi odpowiednikami), jak i gramatyczna: dokładne oddawanie łacińskich konstrukcji oraz form fleksyjnych (niezgodne z polską gramatyką) oraz gromadzenie wielu odpowiedników leksykalnych jednego elementu.

\section{Źródła}

Msza III, rkps Zakładu Narodowego im. Ossolińskich we Wrocławiu, sygn. 2080/II.

Msza IV, rkps Biblioteki Jagiellońskiej, sygn. Akc. 150/54.

Msza XII, rkps Archiwum Archidiecezjalnego w Gnieźnie, nr MS 60.

Msza XVI, rkps Biblioteki Narodowej w Warszawie, sygn. Akc. 9889.

\section{Literatura}

GeSner A., 2011, Glosy w Rozmyślaniu przemyskim. Wyniki analizy formalnej i perspektywy badań, „Kwartalnik Językoznawczy” nr 3, s. 89-97.

LeŃCZuk M., 2013, Staropolskie przekazy kanonu Mszy Świętej. Wariantywność leksykalna, Warszawa.

MasŁej D., 2016, Modlitwa Pańska w polskim średniowieczu. Znad staropolskich rękopisów, Poznań.

MASŁEj D., w druku, Zbiór glos czy tekst? Kazania augustiańskie jako problem edytorski i naukowy, [w:] K. Borowiec i in. (red.), Jak wydawać teksty dawne?, „Staropolskie Spotkania Językoznawcze”, t. 2, Poznań.

Mika T., 2015, Tekst staropolski jako odmienny obiekt badań? W poszukiwaniu narzędzi opisu, „LingVaria” nr 2 (20), s. 235-250, [on-line:] http://dx.doi.org/10.12797/LV.10.2015.20.18.

Pietkiewicz R., 2013, Tradycja rękopiśmienna polskich przekładów biblijnych od XIII do XVI wieku, „Wrocławski Przegląd Teologiczny” nr 2 (21), s. 29-50.

Twardzik W., 1994, Glosy w „Rozmyślaniu przemyskim”, „Teksty Drugie” nr 3, s. 155-165.

Wydra W., 1973, Polskie dekalogi średniowieczne, „Silva Medii et Recentioris Aevi”, nr 2, Warszawa.

Wydra W., Rzepka W.R., 2004, Chrestomatia staropolska. Teksty do roku 1543, wyd. 3, Wrocław. 


\section{A contribution to the discussion on Old Polish text. Analysing the Canons of the Mass Summary}

The paper analyses selected mediaeval Canons of the Mass from a text linguisctic perspective. It focuses on four monuments which are considered glosses from the point of view of the formal criterion (the placement on the page), and texts from the point of view of their shape (the degree of development). The analysis includes the graphical shape of the annotations, the syntax of the Polish passages with respect to the Latin prototype, the base and the completeness of the translation. This multi-faceted analysis leads to the conclusion that mediaeval Polish glosses to the Canons of the Mass consitute not a text but a complete collection of glosses. This conclusion is justified by both their graphical and grammatical shape: verbatim rendering of Latin constructions and inflections (inconsistent with Polish grammar), and accumulation of multiple lexical equivalents of a single element. When working with this kind of monuments, one needs to take into account not only the quantitative criterion (completeness of the translation) but also the function of the whole that the scribe created, and the intention of the author. 